\title{
A pioneering era of accounting history: The contributions of nineteenth-century Italian literature and its enduring

\section{Stefano Coronella}

Parthenope University of Naples, Italy

\author{
Valerio Antonelli
}

University of Salerno, Italy

\section{Alessandro Lombrano \\ University of Udine, Italy}

\begin{abstract}
The aim of this article is to show the contributions to the accounting history literature made by Italian scholars working in the second half of the nineteenth century. These scholars comprised the world's first community of academics, practitioners, office bearers and historians dealing in a systematic way with accounting's past. They invented the narrative of accounting history and their historical re-enactments on relevant topics have been the basis for further historical research for many years. The last decades of the nineteenth century saw great development in historical studies of accounting, both in and outside of the academies. These studies were mainly of three types: (a) general histories, which examined the evolution of accounting practices from antiquity to the late nineteenth century; (b) investigations of the origins of doubleentry and Pacioli; and (c) research on the evolution of accounting practices. Some of the most prominent books and papers published in this period have become widely known abroad. This article contributes to knowledge of early international accounting historians and can be linked to the field of accounting history today. It also demonstrates the widespread dissemination of this early Italian literature around the world, thereby forming the first example of international accounting history.
\end{abstract}

\section{Keywords}

historiography, international dissemination, Italy, national tradition, nineteenth century

\section{Corresponding author:}

Stefano Coronella, Department of Business and Economics Studies, Parthenope University of Naples, Via Generale Parisi, I3, Napoli 80I32, Italy.

Email: stefano.coronella@uniparthenope.it 


\section{Introduction}

Historiography is concerned with the problems of object and method in accounting history, as it is concretely studied in various countries and periods of time. Interest in what has been written about accounting history is recent, especially in Anglophone literature, with it becoming particularly relevant in the last thirty years. As demonstrated by Carnegie (2014a, 2014b), there are a variety of reasons why this is the case. In particular, the recent interest emerges from a theoretical paradigm that connects accounting to the organizational, social and political context in which it is inserted and which at the same time it influences (Burchell et al., 1980; Hopwood, 1983, 1987; Miller et al., 1991; Chapman et al., 2009). It helps us understand how accounting history could play a role in academic, social and economic contexts, explaining why and how the conceptions of history, the research methods, the institutions, subjects and periods are chosen (Gomes, 2008; Richardson, 2008; Gaffikin, 2011; Gomes et al. 2011).

The main factors influencing historiographical development concern the space and the time in which historical research is conducted.

\section{Space}

One of the most important factors influencing the development of historical studies is the national tradition. According to many scholars, accounting history is not a field of study with standards that could be defined as "global". Instead, these standards tend to change according to the country and to the community of scholars. Accounting history presents different features that are distinctive in different nations (Carnegie and Napier, 2002; Carmona and Zan, 2002; Zan, 2005; Carnegie and Rodrigues, 2007; Walker, 2009). The most relevant features include: the purposes of history (such as legitimating national supremacy, affirming local accountants' communities, and so on), the institutions involved in academic research, the language adopted (generally the mother tongue), and the publication forms (e.g. books versus papers) (Zan, 1994; Lukka and Kasanen, 1996; Carmona, 2006).

In this respect, the Italian case is the most emblematic. Because it unites cultural, methodological and sociological circumstances, the historical research conducted in Italy has some peculiar traits of great interest to the international community (Parker, 1993; Walker, 2005; Carnegie and Rodrigues, 2007). Therefore, it is potentially beneficial for those who are not Italian to learn more about accounting history research conducted by Italian scholars (Edwards, 2009).

To respond to this potential interest, historiographical research in Italy has made giant leaps in the last twenty years. Referring only to papers published in international refereed journals on the topic, we can distinguish three historiographical approaches:

- The first approach consists of the literature review. The main historical works and their authors are reviewed in the works of Zan (1994), Galassi and Mattessich (2004), Viganò and Mattessich (2007), Carmona (2007) and Mattessich (2008).

- The second approach consists of meta-analysis. It includes papers that provide statistical investigation of the accounting history literature coming from Italian scholars. This approach is applied by Cinquini et al. (2008) and Antonelli and D'Alessio (2011, 2014).

- The third approach is biographical. For example, Garner (1976) and Padroni (1976) recall the life and works of the prominent accounting historian Federigo Melis. Galassi (1996) presents the figure of Tito Antoni (1915-2000), an accounting historian of the mid-twentieth century. Finally, Sargiacomo et al. (2012) and Antonelli and Sargiacomo (2015) discuss the contributions, respectively, of Fabio Besta (1845-1922) and of Alberto Ceccherelli (18851958) to accounting history research. 
However, despite the many efforts made, research by the Italian community of accounting historians is still little known to the English-speaking contemporary public (Carmona and Zan, 2002; Walker, 2005). Historical research in international circles has not yet covered the diverse panorama of the accounting history contributions published in Italian. The English-speaking international community has some unavoidable difficulties in analysing historical research conducted in Italy, mainly due to the difficulties of comprehending publications that have been written for native speakers of Italian.

\section{Time}

It is not easy to identify the starting point of any nation's accounting history. To show that a work, or set of works, is devoted to accounting history, the object, method and style need to be defined based on a set of criteria (Previts et al., 1990a; Napier, 2006; Carnegie and Napier, 2012). Although the identification of this starting point is, therefore, conventional, there is no doubt that the scholars of some countries, like Italy, have taken the first steps in the field of the accounting history (Hernàndez-Esteve, 1997: 620). Mattessich added that towards the end of the nineteenth century, and especially in the twentieth century, this historical interest spread to the UK, the US and to many other countries (Mattessich, 2003: 146). Antonelli and D'Alessio surveyed 157 publications (books, book chapters, and articles in journals) on accounting history topics that were published in the nineteenth century in Italy, showing that the emergence of an academic community and professional legitimation were the most important factors influencing the development of this literature (Antonelli and D’Alessio, 2014: 91).

\section{Aim and structure of the article}

In the last twenty years, there have been only a few papers published in Anglophone journals that are dedicated to Italian studies of accounting history and the relevance of the studies of accounting history conducted in Italy before 1900. This leaves a large free space for historiographical investigation into the less recent Italian studies of accounting history.

The objective of this article is to investigate the contributions to accounting history coming from the Italian tradition during the second half of the nineteenth century, and the relevance of these contributions for international debate now and in the future. Their importance emerges for several reasons. First, this historical literature represents the first body of studies that deals in a systematic way with accounting's past, in Italy and abroad, inventing the concept of the accounting history narrative. Secondly, it involves a wide network of academics, practitioners, office bearers and historians tout court. Third, some monographs on relevant topics are identified that have provided the basis for further historical research around the world.

The present article is a literature review focusing on the scholars and their contributions, which differentiates it from Antonelli and D'Alessio (2014). The article enriches what has already been studied by Zan (1994) who, in his extensive literature review, cites some accounting historians writing in the nineteenth century (Barduzzi, Bariola, Besta, Brambilla, Cerboni and Ghidiglia), but focuses almost exclusively on the historical work of Bariola. In contrast, this article takes into consideration 97 authors and 151 works published in the second half of the nineteenth century. In particular, it takes into consideration accounting historiy studies in a strict sense, that is, the author is explicitly dealing with accounting, and the work is entirely devoted to accounting history matters.

The structure of the article is as follows. In the second section we provide our research methodology, describing how we selected the literature involved in our analysis, and the steps that were 
followed. The third section provides an overview of the literature on Italian accounting history in the second half of the nineteenth century. In the fourth section we analyse the international dissemination of the aforementioned Italian accounting history literature, with reference to citations of the major books and articles published in the international network of historical research. We show in which thematic areas the citations are concentrated on. The fifth section summarizes the main leanings of the international literature, relating them to the thematic areas shown in the fourth section, and, for each of them, analyses the role played by Italian literature in the international debate. The sixth section offers some critical and interpretative contributions. In the conclusion we summarize our results, identify the limits of the research, and make some proposals for future investigation.

\section{Methodology}

To achieve the above-mentioned objectives, all works we could locate that were devoted exclusively to accounting history and were published in the second half of the nineteenth century in Italy were taken into account. Therefore, we have excluded works that deal with accounting history only in part. The materials comprised books, articles and conference proceedings.

The publications considered here have been identified based on the references of five bibliographies - a generalist (Pagliaini, 1901-5) and four specialists (Cerboni, 1889; Massa, 1912: 291-375; Giannessi, 1964; Arena and Gambino, 2008). The four specialized bibliographies represent the only source of accounting and accounting history published in Italy to date. Those of Cerboni and Massa include monographs and articles, and those re-printed as pamphlets. The bibliographies of Giannessi and Arena and Gambino include all monographs and articles.

The comprehensiveness of our survey is ensured by the fact that all the printed volumes (and the relative indexing) are present and deposited (since 1869) in the State Libraries of Rome and Florence. Further, as far as the articles are concerned, all the years we examined were reviewed by consulting some of the most important Italian libraries: "Ca' Foscari” University Library of Venice; "Intronati" Municipal Library of Siena; and the Public Libraries of Novara and Pinerolo. We analysed the citations of these works firstly by consulting Google Books and Google Scholar and secondly by consulting internet sites publishing free reading texts; in particular we consulted https://archive.org/ and http://gallica.bnf.fr/.

The search on Google Books and Google Scholar was performed by inserting in its search field all the authors and the titles of the 151 surveyed Italian works. Without entering any filter, it was possible to identify all the works present on Google Books and the Google Scholar databases that cited these 151 publications. In some cases, the entire work was available; in other situations, only the part referring to the citation was found. However, this was enough, as our citation analysis was quantitative.

Many other works (not indexed on the sites mentioned above) have been traced and subjected to feedback, as we intended to be as comprehensive as possible. In particular, the research was followed up by direct consultation of the works available at the historical library of the Department of Economics and Management of Pisa, and the library of the Faculty of Economics, University "La Sapienza" of Rome. This was done in order to assess the impact of the 151 publications on the international literature of a later time. The citation analysis was conducted on works written in English, French, German and Spanish. The research included all the other works picked out in the digital archives mentioned above. We also considered citations appearing in the main texts of accounting history, but not in digital databases of free reading.

Since the goal was to assess the impact of Italian work on foreign work, we first established the existence of Italian authors' quotations to analyse; then we examined the impact of Italian literature 
on the international literature. We considered foreign publications which contained at least one reference to Italian literature, assuming that the absence of quotations indicated an absence of knowledge or influence. When works quoted nineteenth-century Italian authors, we directly passed those works to the second stage of research. By doing so, we built a citation map of major works of potential interest.

Once the foreign literature was selected, we identified thematic areas on which the quotations were polarized. We than calculated statistics showing the historical events most concerned by the citations. Based on this data, we were able to identify the international debates that were subject to the highest number of Italian quotations.

\section{An overview of Italian accounting history literature in the second half of the nineteenth century}

Both accounting academics and practitioners strategically sought to retell the history of Italian accounting after the unification of Italy. They were involved in a strong effort to investigate and to disseminate the history of accounting practices, treatises and theories, and of the accounting profession in order to affirm a cultural primacy in the accounting field, according to the nationalist Zeitgeist dominating the period. At the same time, academics and practitioners for the first time faced many historiographical problems and solved them in different manners. This was the case both in terms of subjects, periods and places, and in terms of perspectives (Antonelli and D'Alessio, 2014; Coronella et al., 2015).

Fabio Besta was a pioneer in the study of accounting history. Besta undertook extensive historical studies, making this research area a cornerstone of his scientific and educational activities (Sargiacomo et al., 2012). However, the contribution of Besta cannot be taken into account in the present work for three main reasons. First, all his works offer historical references within larger works and are therefore not classifiable as accounting history articles or monographs. Second, none of the works he wrote in the nineteenth century deal with historical themes. Finally, the historical excerpts of the second and third volumes of his Opera Omnia, La Ragioneria relate to a historical period later than the target of our analysis. La Ragioneria, composed of three volumes, was completed and printed only in 1909-1916 (Besta, 1909-1916). The first volume, first published in 1891, contains historical references. Extensive historical insights are contained in the second and third volumes, respectively of 1910 and 1916 (Sargiacomo et al., 2012: 257-261). The importance of Besta's research is not diminished by the fact that his most important writings were published after our period of observation. Besta was, without a doubt, the Italian scholar who gave the most impetus to historical studies of our discipline. So it is only right to quote him in this work, and even to remember that many of his students published important works by the late nineteenth century.

Having said this, we listed and analysed 56 books and pamphlets and 95 papers published in our period of observation. They focused either on "general histories" or on specific issues, periods or thinkers with regard to accounting. Indeed, many authors wrote general histories of accounting. These publications outlined the development of practices, techniques and theories from ancient times to the late nineteenth century, illustrating the most significant stages of this growth. Other publications focused on historical matters and can be classified according to the taxonomy of Carnegie and Napier (1996): studies of surviving business records of firms; biography; institutional history; and public sector accounting. For our purposes, we added three categories: reprint of ancient works; accounting theories; other works (see Table 1 for this classification by content and Table 2 according to year of publication). 
Table I. Italian books and pamphlets published in the second half of the nineteenth century (by content).

\begin{tabular}{|c|c|c|}
\hline Content & Number & Authors \\
\hline General history & 9 & $\begin{array}{l}\text { Baccarini (I837); Gitti (I878a); Barduzzi (I883); Gitti } \\
\text { (I884); Mannarino (I89I); Ghidiglia (I895); Vitale (I896); } \\
\text { Bariola (I897); Luchini (I898) }\end{array}$ \\
\hline Biographies & 8 & $\begin{array}{l}\text { Gitti (I877); Anonymous (I880); Bonalumi (I880); } \\
\text { Brandaglia (I882); Zambonini (I889); Appiani (I893); } \\
\text { Vianello (I896); Lanfranchi (I897) }\end{array}$ \\
\hline Historical periods & 8 & $\begin{array}{l}\text { Capparozzo (I880); Cuccoli (I88I); Mondini (I } 882) \text {; } \\
\text { Perugini (I888); Zambonini (I894); Brambilla (I896); Rossi } \\
\text { (1896); Brambilla (I898) }\end{array}$ \\
\hline Accounting theories & 6 & $\begin{array}{l}\text { Passerini (I875); Bonalumi (1878); Ministero del Tesoro } \\
\text { (1878); Salvagnini (I879); Lanfranchi (I89I); Saporetti } \\
\text { (1898) }\end{array}$ \\
\hline Institutional history & 4 & $\begin{array}{l}\text { Bosellini (I864); Campi (I879); Luchini (I88I); Campi } \\
\text { (1887) }\end{array}$ \\
\hline $\begin{array}{l}\text { Studies of surviving business } \\
\text { records of firms }\end{array}$ & 3 & Alfieri (|89I); Tavernari (I89I); Dabbene (I893) \\
\hline Public sector accounting & 13 & $\begin{array}{l}\text { Gentile (1878); Rossi (I882); Giardina (I885); Montani } \\
\text { (1886); Giardina (I887); Corradini (I889); Stella (I889); } \\
\text { Salvatori (I890); Rigobon (I892a); Brambilla (I894); Alfieri } \\
\text { (1896); Bachi (1896); Bachi (I899) }\end{array}$ \\
\hline Reprint of ancient works & 2 & Gitti (I878b, I882) \\
\hline Other works & 3 & Anonymous (I884); Anonymous (I888); Cerboni (I889) \\
\hline Total & 56 & \\
\hline
\end{tabular}

Table 2. Italian books and pamphlets by year.

\begin{tabular}{llllll}
\hline Year & $\#$ & Year & $\#$ & Year & $\#$ \\
\hline 1837 & 1 & 1883 & 1 & 1892 & 2 \\
1864 & 1 & 1884 & 2 & 1893 & 2 \\
1875 & 1 & 1885 & 1 & 1894 & 2 \\
1877 & 1 & 1886 & 1 & 1895 & 1 \\
1878 & 5 & 1887 & 2 & 1896 & 6 \\
1879 & 2 & 1888 & 2 & 1897 & 2 \\
1880 & 3 & 1889 & 4 & 1898 & 2 \\
1881 & 2 & 1890 & 1 & 1899 & 1 \\
1882 & 4 & 1891 & 4 & Total & 56 \\
\hline
\end{tabular}

With respect to the books, it is interesting to note that two of them (Bariola, 1897; Luchini, 1898), among the best known and cited, were the result of a competition. With the aim of spreading knowledge of accounting, in 1894 the Lombard Historical Society announced a contest for the best unpublished book on the history of accounting. The competition specifically concerned the "history of Italian accounting" and was the first of its kind on this subject in Italy. The award was particularly attractive, being 1,200 lire (Italian currency), which at the time corresponded to 18 months of a middle-class worker's wage. The winner was the manuscript of Bariola, which however underwent a further review before its publication. The author was asked to fill in some gaps, 
Table 3. Number of historical articles appearing by the end of the nineteenth century.

\begin{tabular}{lc}
\hline Journal & Number of historical articles \\
\hline Rivista di contabilità & 6 \\
II Ragioniere & 61 \\
Rivista di amministrazione e contabilità & 28 \\
Total & 95 \\
\hline
\end{tabular}

modify some part of the work (i.e. where the job of the accountant was described) and reduce the overall length. The full manuscript (more than a thousand pages) was revised by the author and finally published in book form as The History of Italian Accounting (Bariola, 1897), printed at the expense of the Lombard Historical Society.

The second prize was awarded to the manuscript of Luchini, which was subsequently published as a monograph entitled History of Italian Accountancy (Luchini, 1898), having been selected for inclusion in the treaty of nine volumes edited by Massa and published between 1896 and 1899 under the titled Profession of the Accountant. For the above reasons, the volumes of Bariola and Luchini have been widely circulated and have been reprinted many times.

Some journals dedicated a considerable amount of space to our themes. We refer, specifically, to the Rivista di contabilità (Accounting Journal), founded and directed by Massa, and the Il Ragioniere (The Accountant), founded and directed by Gitti, as well as the Rivista di amministrazione e contabilità (Administration and Accounting Journal), founded and directed by Mondini.

Overall, 95 historical papers were published by the end of the nineteenth century, with some of them divided into parts that appeared in different numbers of the mentioned journals (these were counted as single articles). Table 3 shows the distribution of these contributions.

Other historical articles were published elsewhere. These are very isolated cases and may be of little interest to scholars. We checked the indexes of all issues of the major Italian magazines not already mentioned, in particular Il logismografo (The Logismograph) and La scienza dei conti (Accounting Science). The second of these offers two historical works (one page each) which are related to the profession of accountant. Some historical papers were also published in other journals that did not have an accounting focus. However, we confined our study to specialized journals only.

All the 95 papers mentioned above appeared between 1879 and 1900, representing an average of more than four articles per year (this figure rises to 6.5 if we count the individual parts of articles that were spread across more than one issue). Table 4 provides further details on when the 95 articles were published.

The number of articles is significant in understanding the interest in accounting history in the last two decades of the nineteenth century. Looking at the topics, an extreme variety of research emerges, with reference to biographies, specific historical periods, accounting practices, accounting theories and public sector accounting in ancient times. Finally, some papers were devoted to the origins of the accounting profession in Italy in the sixteenth century through to its evolution in the nineteenth century.

\section{The first step: Nineteenth-century Italian accounting history citations in international literature}

The first stage of this research was to design a citations map related to the 151 historical works we identified and examined. We can extrapolate the contribution of the major Italian authors, pointing out the number of works in which they are quoted and the total number of citations. The latter index 
Table 4. Distribution of historical articles appearing by the end of the nineteenth century.

\begin{tabular}{lllllc}
\hline Year & $\begin{array}{l}\text { Number of } \\
\text { articles }\end{array}$ & Year & $\begin{array}{l}\text { Number of } \\
\text { articles }\end{array}$ & Year & $\begin{array}{l}\text { Number of } \\
\text { articles }\end{array}$ \\
\hline 1879 & 3 & 1886 & 4 & 1894 & 7 \\
1880 & 7 & 1887 & 4 & 1895 & 9 \\
1881 & 7 & 1888 & 3 & 1896 & 8 \\
1882 & 5 & 1889 & 4 & 1897 & 10 \\
1883 & 1 & 1890 & 3 & 1898 & 7 \\
1884 & 1 & 1891 & 5 & 1899 & 1 \\
1885 & 0 & 1892 & 4 & 1900 & 0 \\
& & 1893 & 2 & Total & 95 \\
\hline
\end{tabular}

is obtained by adding all the footnotes or notes in the text referring to the same author. The first index gives us an idea of the circulation of the works, while the second indicates how intensely they were used as a secondary source. We then distinguished the authors according to their mother tongue and constructed four columns: Anglophone; Italians writing in English; Latin; and German. We included Italian-American authors in "Anglophone", and French, Portuguese, and Spanish authors in "Latin".

Table 5 shows that Bariola (1897) and Cerboni (1889) are the most disseminated works internationally, with 20 and 15 international citations respectively. Next come Alfieri (1891) with 13 citations, Vianello (1896) with 10, and Gitti (1878b), Bonalumi (1880) and Rigobon (1892a) with nine each.

The works most commonly quoted are those of Bariola (75 quotations), Alfieri (29 quotations) and Cerboni (18 quotations). It should be noted that, while the works of Bariola and Cerboni are general histories, the topic of Alfieri's book is more specialized (i.e. accounting practices in Venice in the fifteenth century). However, this is a topic of great interest to the community of accounting historians.

Books on accounting history published in Italy in the second half of the nineteenth century are widely cited, for three main reasons. First, these works represent a secondary source of reference because they contain excerpts of printed volumes (from the Tractatus of Pacioli onwards) - being useful data for reconstructing both biographies and documents of historical interest. Second, the critical content of such research indicates the complexities of accounting's past in Italy. Third, the works, as a whole, are more recently cited as a significant example of how the cultural, scientific and academic behaviour of accounting scholars can operate in specific conditions and contexts.

That being said, one should emphasize that some limitations may have prevented Italian researchers from having a wider impact and obtaining a larger number of citations. In the absence of such limitations, the impact of nineteenth-century Italian researchers would have been more substantial.

A first significant limitation has to do with availability: foreign libraries and scholars did not have easy access to these writings. In effect, most volumes were printed in a handful of copies by local presses. Something similar holds for journal articles. The journals concerned were administered locally by professional associations dealing primarily with professional bookkeeping (Massa, 1912: 377-380). For this reason, they had limited distribution even in Italy. Outside of Italy, of course, they were difficult to find and therefore it was hard to generate interest among peers. 


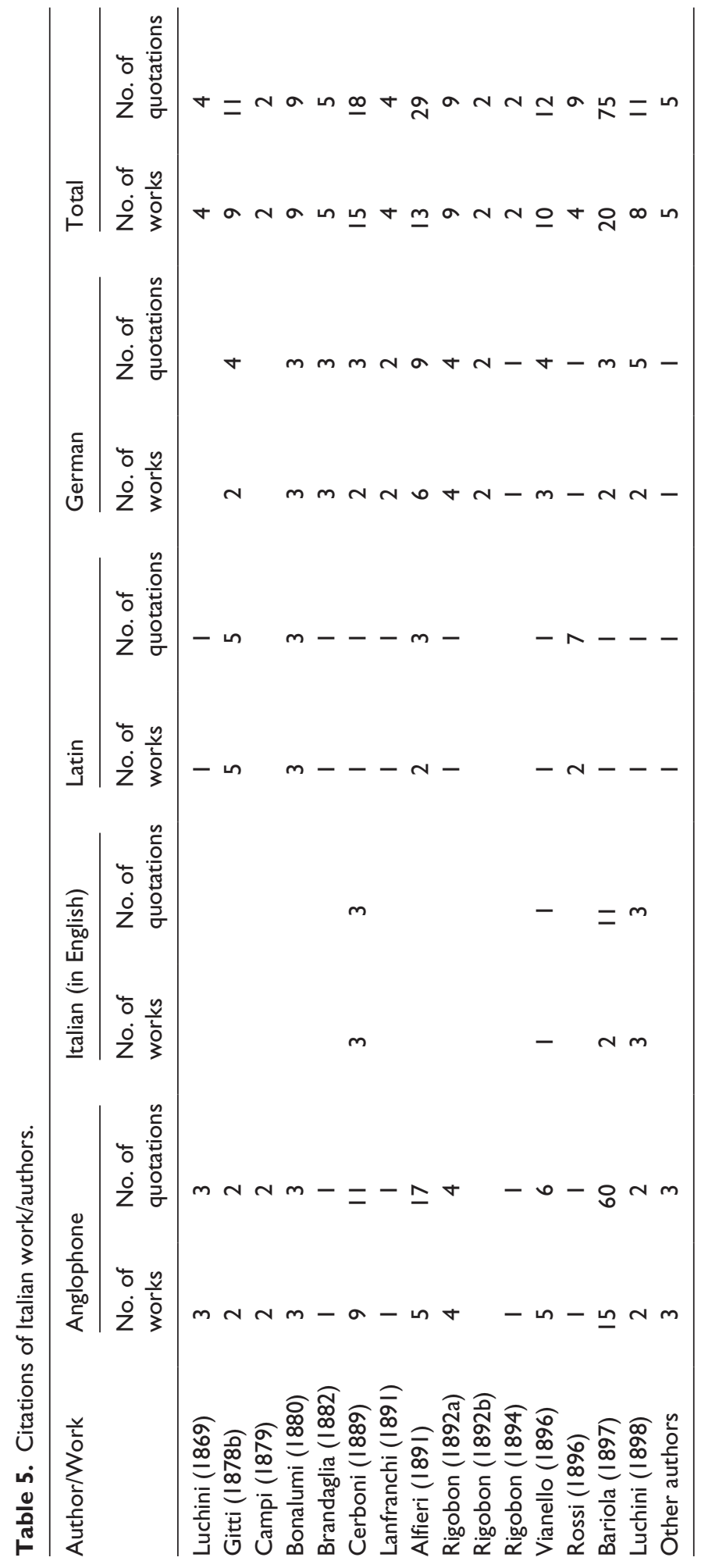


Table 6. Most cited Italian accounting historians.

\begin{tabular}{lll}
\hline Name & Lifespan, where known & Job \\
\hline Vittorio Alfieri & $1863-1928$ & Lecturer in Accounting \\
Plinio Bariola & - & Professional Accountant \\
Francesco Alberico Bonalumi & $1832-1904$ & Lecturer in Accounting/Clerk \\
Guido Brandaglia & - & Professional Accountant \\
Vincenzo Campi & - & Professional Accountant \\
Giuseppe Cerboni & $1827-1917$ & State General Accountant \\
Vincenzo Gitti & $1856-1945$ & Lecturer in Accounting \\
Giovanni Lanfranchi & - & Professional Accountant \\
Ernesto Luchini & - & Professional Accountant \\
Pietro Rigobon & $1868-1955$ & Lecturer in Accounting \\
Giovanni Rossi & $1845-1921$ & Intendant/Director of Finance \\
Vincenzo Vianello & $1866-1935$ & Lecturer in Accounting \\
\hline
\end{tabular}

Only a few works from the nineteenth century circulated among scholars abroad. In particular, those most cited by foreign scholars are Bariola's book (1897) and the one by Cerboni (1889). This is to be expected for the following reasons:

- Bariola's book is the first systematic work examining bookkeeping history. Moreover, as the winner of an award established by the Historic Lombard Society in 1894, it was published in numerous copies at the expense of the Society (Bariola, 1897: i-ix).

- Cerboni's book was published by the Kingdom of Italy Accounting Department.

It seems, then, that these two works were circulated abroad. This is a consequence, first, of the prestige of the institutions publishing those works, and, second, of the numbers of copies, which far exceeded the average for copies of similar writings.

Undoubtedly, the interest that has been maintained around the issues addressed in the abovementioned historical works contributed in the second half of the twentieth century, and especially in the last twenty years, to a new dissemination of these works to an international audience. On the one hand, libraries of many American and British universities have retrieved the volumes and, in some cases, the original versions have been reproduced. On the other hand, with the digitization of content, scholars from all over the world can now access some original texts on the web. ${ }^{1}$

If availability was the first issue, language constitutes the second. Among foreign scholars who had access to those works, those who had fewer troubles were academics whose first language was part of the Neo-Latin group, and the English-speaking scholars of Italian origin, such as Peragallo, a son of Italian immigrants. As far as we know, no authors cited in the present work (besides those of Italian origin) had a good command of Italian.

The scarce circulation abroad of Italian writings and the limited knowledge of the Italian language are the two major factors limiting access and the number of citations of these works. Table 6 provides some short biographical information on the most prominent Italian authors.

The quotations enumerated in Table 5 were reclassified according to the themes to which they refer. The results are shown in Table 7.

The citations are principally on these issues: (a) accounting systems in the Roman Empire (12 citations); (b) the origins of double-entry bookkeeping (hereinafter: DEB) (36 citations); (c) Luca Pacioli (31 citations); (d) bookkeeping treatises published after Pacioli (23 citations); and (e) miscellaneous other issues (20 citations). 
Table 7. Italian accounting history citations according to subject.

\begin{tabular}{|c|c|c|c|c|c|c|}
\hline Author/Work & $\begin{array}{l}\text { Accounting } \\
\text { systems in the } \\
\text { Roman Empire }\end{array}$ & $\begin{array}{l}\text { Origins of } \\
\text { double entry } \\
\text { bookkeeping }\end{array}$ & $\begin{array}{l}\text { Luca } \\
\text { Pacioli }\end{array}$ & $\begin{array}{l}\text { Bookkeeping } \\
\text { treatises }\end{array}$ & $\begin{array}{l}\text { Other } \\
\text { issues }\end{array}$ & $\begin{array}{l}\text { Total } \\
\text { no. of } \\
\text { citations }\end{array}$ \\
\hline Luchini (1869) & & & & & 4 & 4 \\
\hline Gitti (1878b) & & & 9 & & & 9 \\
\hline Campi (1879) & & 2 & & & & 2 \\
\hline Bonalumi (I880) & I & 5 & & 3 & & 9 \\
\hline Brandaglia (I882) & & & 5 & & & 5 \\
\hline Cerboni (1889) & & & & II & 4 & 15 \\
\hline Lanfranchi (|89I) & & 4 & & & & 4 \\
\hline Alfieri (I89|) & & 9 & & 4 & & 13 \\
\hline Rigobon (I892a) & & 9 & & & & 9 \\
\hline Rigobon (I 892b) & & 2 & & & & 2 \\
\hline Rigobon (I 894) & & & & 2 & & 2 \\
\hline Vianello (1896) & & & II & & & 11 \\
\hline Rossi (1896) & 4 & & & & & 4 \\
\hline Bariola (1897) & 7 & 2 & 5 & 1 & 5 & 20 \\
\hline Luchini (I898) & & I & 1 & 1 & 5 & 8 \\
\hline Other authors & & 2 & & 1 & 2 & 5 \\
\hline Total & 12 & 36 & 31 & 23 & 20 & 122 \\
\hline
\end{tabular}

\section{The second step: The role played by Italian historical literature in the international debate}

\section{Accounting practices during the Roman Empire}

The history of accounting practices during the Roman Empire is founded on very little archival evidence. The Romans did not use rules or paper, but wax tablets. These tablets were erased and reused many times. As a consequence, they were lost (Green, 1990; Laurence, 2012) and, up to now, only secondary sources are available, mainly from the orations of Cicero (Davies and Swain, 2010; Bunson, 2013). As a result of this limitation, the international accounting history debate focuses mainly on two aspects.

The first issue concerns the existence and use of accounting systems by the government, families and Roman private estates. Research in this field emphasizes the importance of accountability in the management of public affairs, both during the Republic and the Empire, and the control, even remotely, of private economic activities (Rathbone, 1994; Oldroyd, 1995; Chatfield, 1996; Macve, 2002; Oldroyd and Dobie, 2009: 96-99). In this context, we can keep in mind the "general histories" (Brown, 1905: 29-40; Woolf, 1912: 37-44; Vlaemminck, 1956: 34-38) in the chapters concerning the Republic and the Roman Empire.

The second issue concerns the adoption of DEB by the Romans. At the beginning of the nineteenth century, Niebuhr (1820) claimed to have discovered in the Vatican fragments of the oration of Pro Fonteio some evidence that the Roman quaestors used DEB. This thesis is tentatively if not conclusively accepted by Most (1976: 5-6), Eddie and Murphy (1985: 38) and Aho (2012: 64-65). Others reject the hypothesis of Niebuhr as they locate the origins of DEB in the middle Ages (Smith, 1954; De Ste Croix, 1956: 33-50; Jouanique, 1968; Glautier, 1972). De Ste Croix, in particular, argues that the Romans did not adopt the DEB; indeed, the Roman use of numerous books 
(Adversaria, Codex accepti et expensi, Codex rationum, Kalendarium; see Bonalumi, 1880 and Gomberg, 1929: 8, 11) does not constitute proof in this sense.

Macve (1985: 422-425), while criticizing De Ste Croix because of his ignorance of a fragment of a speech of Cicero and of a papyrus in Karanis from Egypt, believes that the Romans were not aware of the DEB method. In fact, he claims, they were not interested in DEB as they were primarily interested in profit calculation (Macve, 1985: 425-426). Even Green, who has studied the Roman archaeological finds, categorically denied the possibility of a complex accounting system (Green, 1990: 65).

The major contributions of the late nineteenth century are those by Rossi and Bariola. Rossi was charged by the Italian government to pursue the matter raised by Niebuhr. Rossi (1896) focused on the question of whether the Romans might have already known DEB. Moreover, Rossi's work is the first to question the theory of Niebuhr and provide extensive documentation about it. He is quoted by Kheil (1906: 9), Dupont (1925: 19) and Martinelli (1977: 9-10). Minaud, a contemporary Roman Empire historian, quotes the book of Rossi many times (Minaud, 2005: 20, 44, 45, 46, 55, 61). All refer to Rossi's central thesis that the Romans did not employ DEB.

Bariola (1897) responded to Rossi to refute his thesis. After explaining the practices and the books of the Romans, Bariola argues that they practised a rudimentary form of DEB. Quotations from Bariola's work are found in Kheil (1906: 13), Kats (1930: 311), Murray (1930), Green (1930: 273), De Roover (1937: 271), De Ste Croix (1956: 67) and Minaud (2005: 369). These scholars cite Bariola to strongly disagree with his thesis and to reaffirm that the Romans did not know DEB and that the origins of this accounting technique arose much later; that is, in the Middle Ages. Kats, in his work on the subject (1930: 311), also refers to Brambilla (1896), reporting a quotation in Italian against the thesis of Bariola: "As far as Rome is concerned, if we can know which books they used, we do not know how the scriptures were kept" (Brambilla, 1896: 11).

Two questions debated by accounting historians from around the world - the existence of an accounting system in the Roman world and, above all, the adoption of DEB - have found pertinent references in the Italian studies of the late nineteenth century. Bariola and Rossi are the two best known and consulted Italian authors, especially on the second theme. Moreover, they first (opening the discussion on the historical work of Niebuhr) proposed the main arguments for and against the thesis of DEB in Roman times. Finally, they both made available original documents, in Latin, facilitating the work of later scholars.

Compared to the themes which will be discussed below, the studies on accounting practices in the Roman Empire conducted by the late-nineteenth-century Italian scholars seem to have less appeal for foreign scholars. Possible explanations are threefold. First, there was, and remains, very little available evidence. As a consequence, there are many possible inferences and further work can be done in the field by Italian historians who already working on site (in the archives and in the archaeological excavations of Roman remains scattered throughout Italy). Second, the evidence is all written in Latin, a language quite accessible to the international community of historians (who have sometimes studied this subject in their degree course). So, although non-Italian scholars could directly access the evidence without the help of an Italian historian, they appear to have chosen not to . Finally, the historical question, though debated to this day, always covers the same evidence (except for some recent archaeological discoveries), now well known to all the experts (in especially the Oration of Cicero) and is gradually losing appeal.

\section{The origins of $D E B$}

The international literature about the origins of DEB is probably the longest and most controversial. Many analyses have been conducted and several viewpoints advocated. Some studies trace the 
invention of DEB to the Indians (Nigam, 1986; Singhvi, 1995), to the Greeks (Filios, 1984: 172), to the Arabs (Zaid, 2000, 2001, 2004), to the Incas (Jacobsen, 1964), to some populations from Africa (Sy and Tinker, 2006) or even to the accounting of the Sumerian-Babylonians (Mattessich, 1989; De Sà, 1995: 97).

The line of studies investigated by the historical literature of the late nineteenth century, at issue here, states that the origins of DEB should be placed during the long phase of formation of the commercial capitalism of Commons and Lords in the late Italian Middle Ages. In this scenario, considering the number of their citations, it is possible to assess the impact and the spread of major Italian contributions for the period analysed, namely those of Campi (1879), Alfieri (1891), Lanfranchi (1891) and Bariola (1897).

Locating the origins of DEB in Italy during the Middle Ages. A first group includes the studies that place the origins of DEB in Italy during the Middle Ages. This group provides preliminary and very approximate reconstructions and, as a result, wonders about the circumstances and the causes that favoured the emergence of this technique (Jäger, 1874; Ward et al., 1903; Brown, 1905: 93-134; Woolf, 1912: 159-164; Dupont, 1925; Kats, 1929, 1930; Murray, 1930: 51-78; Doren, 1934; De Roover, 1937, 1956, 1958; Amzalak, 1943).

Sometimes accounting practices and accounting treaties are confused, notably by associating the origins of the DEB with the publication of the work of Pacioli or making the Tractatus a primary source of the basic accounting practices of the time (Kheil, 1902, 1906; Penndorf, 1933; Littleton, 1933: 22-40). DEB is considered the central event in the history of accounting practices and, more generally, of accounting history; the period in which it was born is then the most important in understanding all the future developments of accounting theories (Littleton, 1933).

Many details are given about the origin of DEB in the Italian literature relating to the Middle Ages (Lane, 1944, 1945; Lee, 1973, 1977; Williams, 1978; Var, 1981; Nobes, 1982; Bresnahan Menning, 1993; Mills, 1994; Morrisson, 2002; Paton and Easton Law, 2010). This first line of research is relevant to the description of DEB and its celebration as the 'Big Bang' of accounting world history, and it makes extensive use of the contributions of Italian studies. Campi (1879) is quoted by Brown (1905: 39) on medieval accounting practices during the papacy (from the year 1001). Lanfranchi's volume, dated to 1891, reproduced the original images of the account books of the Mastri Massari of Genoa (1340). For this reason, Lanfranchi's work is quoted by Kheil (1896: 125, 1906: 5) and by Vlaemminck (1956: 54). Alfieri's work on Venetian medieval companies (1891) is cited by Littleton $(1928: 395 ; 1933: 105,108)$ as the source of an example of DEB writings reproduced by him, coming from an Andrea Barbarigo account book of 1430; in Penndorf (1933: 7), contending Sieveking's opinion of the Venetian company Soranzo's account books; and in Amzalak (1943). Lane (1944: 156-175; 1945) makes extensive reference to Alfieri (1891: 82101) in his reconstruction of the accounting practices of Andrea Barbarigo, a Venetian merchant. Even Var (1992: 118, 120) and Morrisson (2002: 217) make wide use of the accounting reconstruction of Venetian companies practices of the fifteenth century; they are both interested in Jachopo Badoer.

The work of Rigobon on Tuscan medieval companies (1892a) is quoted by Ward (1903: 939), Penndorf (1933), Doren (1934: 715), Bresnahan Menning (1993: 215) and Paton and Easton Law (2010: 16), while the other volume of Rigobon (1892b) is cited by Gomberg (1912: 81). Penndorf (1933: 16) refers to Bariola with regard to Florentine account books (Penndorf, 1933: 23). Many images of Italian medieval account books (1273-1524) from Bariola's book are reproduced in Littleton (1933: 102, 104, 105, 106).

The work of the Italian accounting historians contributed to the international debate regarding the origins of DEB, from two points of view. First, they looked at the problem through the analysis 
of the accounts books of medieval companies, and not by examining the content of the treatises on bookkeeping. Second, they allowed the authors of a later period to indirectly examine those accounts books that Italian historians, first, have identified and reproduced in their volumes. Thus, they have then argued for the idea, accepted by many scholars in other parts of the world, that the origin of DEB, originally intended as a technical accounting practice adopted by merchants and rigorously documented by archival evidence, had been found in Italy in the fourteenth and fifteenth centuries.

The Italian region in which DEB began. The second group of writings on the origin of the DEB is subsequent to first. It focuses on a specific aspect: the authors wonder in which Italian region - and therefore in which political, economic and social context - DEB was born. To answer this question, they face another issue: what criteria are necessary to label an accounting system as DEB? Depending on the criteria used, different answers were given about the origins of DEB: that is, pointing to Venice, Milan, Genoa or Florence (Woolf, 1912: 159-163; De Roover, 1937, 1955, 1956; Peragallo, 1938: 3-37; Vlaemminck, 1956: 74-82; Martinelli, 1974, 1977, 1983; Hernàndez-Esteve, 1997; Gleeson-White, 2012; Sangster, 2016). This line of research also draws on some of the Italian texts mentioned above.

The volume of Alfieri (1891) is cited by De Roover (1937: 298; 1943: 406; 1956: 159) due to its extensive reconstruction of the fifteenth-century accounting practices, especially those of Badoer. Bariola's book (1897) is quoted by De Roover (1937: 298) and by Peragallo (1938) - 24 times - with reference to accounting during the period of Charles the Great (1938: 16), to accounting treatises in the Italian Renaissance $(1938: 73,74,76,77,92,93,96)$, and to accounting practices in the modern era (1938: 120, 121, 122, 124). Finally, Peragallo (1938: 143) cites Campi (1879) on medieval accounting practices during the papacy.

The identification of the Italian region where may be found the first trading companies who adopted the DEB is apparently of scarce importance. On the contrary, the location in Genoa, Florence, Milan or Venice of the first books - a question raised by Alfieri, Bariola, Campi - is essential to discuss what is meant, from the historical point of view, by DEB. From this point of view, the main contribution of the Italian authors, here considered, is to have raised this issue, forcing scholars to specify exactly what they meant by DEB (Littleton, 1933; De Roover, 1937; Yamey, 1947). The double-entry method is a particular detection method which is based on a set of predetermined "rules". By accepting different "rules", different results are reached.

$D E B$ and capitalism. The third group of studies on the origins of DEB is inspired by the works of Sombart (1919) and Weber (1922), who carefully investigate the relationship of medieval capitalism trading with the adoption of DEB; they consider one and then the other side of the same coin. The discussion that follows, throughout the twentieth century, sees these two sides part ways. The first side, a minority, supports the thesis of Sombart that DEB encourages the building of conceptual categories such as capital, income and enrichment (Most, 1972, 1976). The second side, the majority, considers the thesis of Sombart unproven because, at least in the first centuries of its use, DEB, as it was concretely manifested, did not guide decision-making (Yamey, 1947, 1949, 1964, 2005).

The thesis of Sombart presents many other limitations, in relation, for example, to the reconstruction of contexts, accounting knowledge, or the concept of value judgements in early capitalism (Winjum, 1971; Martinelli, 1974; Carruthers and Espeland, 1991; Funnell, 2001; Chiapello, 2007). This line of research discusses the relations between capitalism and DEB, drawing inspiration from Italian authors dealing with accounting history in the late nineteenth century. In the second edition of the German version of Der moderne Kapitalismus, Sombart (1919) quoted Brandaglia (1882), Alfieri (1891) and Rigobon (1892a) on page 100 and pages 112-113 and 130; on pages 
100, 129, 131 and 132, Vianello's work is cited. The quotations are all included in the chapter entitled Die Entstehung der kapitalistischen Unternehmung. Sombart reconstructs the events of medieval Italian companies and coeval accounting practices, showing the uses of DEB. The citations refer mainly to the description of Tuscan and Venetian practices of medieval companies. Sombart uses secondary sources, most of which are represented by the Italian works now cited. Sombart also takes into account some theses of Rigobon, such as that DEB has established itself in certain sectors (commercial) and not others (banking, manufacturing) because the first needed capital measures.

In this context, the importance of historical studies conducted in Italy in the nineteenth century is not to be found in a specific contribution to the definition of capitalism, or the explanation of how DEB has influenced the formation of capitalism or vice versa. The importance of these studies, rather, is that the Italian accounting historians, with their works published in the late nineteenth century, influenced decisively the thought of Sombart. He, in fact, bases his argument almost exclusively on evidence found in the accounting history books of the time, particularly those of Alfieri, Brandaglia, Rigobon and Vianello.

\section{Luca Pacioli}

The international literature of accounting history on the life and writings of Luca Pacioli is large and includes hundreds of works: monothematic articles, books, chapters included in volumes of general histories, paragraphs of historical and educational books, and various other references. ${ }^{2}$ Such a literature is polarized around three core principles.

The first group is typical of the earliest studies on the subject, but has survived almost to the present day, and emphasizes the role of Pacioli as the "Father of Accounting" (Hatfield, 1924); that is, as the first author dealing with bookkeeping and the forefather of future generations of accountants (Dupont, 1925; Littleton, 1933; Taylor, 1944; De Roover, 1944; McCarthy et al., 2008). The biography of Pacioli and the description of the main content of his Tractatus are the central themes here (Kheil, 1896; Volmer, 1896; Geijsbeek, 1914; Morison, 1933; Penndorf, 1933; De Roover, 1937: 278-280). The prominence of the author and the primacy of his work are underlined in tones sometimes rhetorical and hagiographic. The Tractatus gained primacy around the world because it was considered the very first book dealing with double-entry bookkeeping. Academics, practitioners and historians unanimously referred to Pacioli as the "Father of Accounting". As such, his work legitimates, both scientifically and morally, the accountancy profession and studies of accountancy. The rapid and explosive circulation of Pacioli's work is also a fundamental affirmation of the primacy of that work (Murray, 1930; Boursy, 1943; Taylor, 1944; Stevenlick and Haulotte, 1975; Stevelinck, 1986).

The second group of historical research on Luca Pacioli is more recent and dismisses the thrilling and celebratory tones of the first literature. The investigations are now analytical and are intended to deepen understanding of detailed aspects of Pacioli's work. Topics include the structure of the Tractatus (Yamey, 1967; Hernàndez-Esteve, 1981), the intuitive explanation of DEB practice as offered by Pacioli, the techniques used, and reflections on practice (Sangster et al., 2012). They are also part of the second group of large monographs contextualized in the late Middle Ages, monographs which report on economy, customs and religiosity (Lopez de Sà, 2004).

The third group involves the entire second half of the twentieth century and questions the primacy of the Tractatus as the first printed work in terms of DEB. In fact, as other cases of plagiarism were seen in that period, it is discussed whether the text was the result of the plagiarism of an earlier work (Gomberg, 1929; Taylor, 1956; Hernàndez-Esteve, 1994; Sangster et al., 2008; Sangster, 2012). 
Within this context, one can evaluate the circulation and the impact of major contributions published by the Italian authors discussed here. The citation numbers of Gitti (1878b), Brandaglia (1882), Vianello (1896) and Bariola (1897) (see Table 6) testify to the relevance of such contributions. Italian authors received the most attention in the works connected with the first line of research, which presents, describes and celebrates Luca Pacioli's figure and work. Gitti (1878b) published a translation into modern Italian of chapter XI of Pacioli's Summa, including 94 explanatory notes. He also included a long preface to introduce the chapter reproduced, and provided background on Luca Pacioli and the development of DEB. The book by Gitti is quoted by Volmer (1896: xv), Geijsbeek (1914: 21), Dupont (1925: 43), Littleton (1933: 76), Stevelinck and Haulotte (1975: 42), Hernàndez-Esteve (1981: 24), Stevelinck (1986: 7), Lopes de Sà (2004: 179) and Sangster et al. (2012: 32).

Brandaglia's book (1882) is entirely devoted to Luca Pacioli, focusing on the accounting contents of the Summa. At first the author deals with Pacioli's life. He defends Pacioli from the accusation of plagiarism by some scholars. Then, the contents of the famous chapter XI (regarding accounts and scriptures) are briefly presented. Quotations from Brandaglia's work appear in Jäger (1889: 4-5), Kheil (1896: 69, 1902: 101-102), Geijsbeek (1914: 21), and finally in Littleton (1933: 76) and Hernàndez-Esteve (1981: 24). All these scholars used Brandaglia's short volume as a source of information about Pacioli's biography and the content of the Tractatus.

Vianello (1896) is cited by Murray (1930: 165, 203), Morison (1933: VI), Penndorf (1933: 63) and Yamey (1967: 64), all of whom reconstruct Pacioli's personal life and the main arguments presented in the Tractatus. The book of Vianello is also cited in Geijsbeek (1914: 21) and in Littleton (1933: 76), in order to correctly spell Pacioli's name. Bariola's opinion was considered very influential in solving the question of spelling Pacioli's name. This can be seen in the citations of Littleton (1933: 76), Boursy (1943: 206) and Taylor (1944: 70). De Roover, in a short essay on Pacioli, disagrees with the above scholars and gives a negative judgement on the volume of Bariola concerning the interpretation of the proper name of the monk, appealing to a tablet erected in Bariola's hometown (De Roover, 1944: 68). Finally, Bariola is quoted by McCarthy et al. These authors share Bariola's opinion in regarding Pacioli as the father of DEB (McCarthy et al., 2008: 188). When considering the second strand of research on Pacioli, Yamey dedicates many pages to the contributions of Vianello (Yamey, 1967: 74-75). Finally, Luchini (1898) is cited by Gomberg (1929: 7).

The fourth strand of research - tackling the issue of the alleged plagiarism - finds an important point of reference in Vianello's book (1896). Vianello's book proposes, inter alia, that the Tractatus was the result of plagiarism. In this regard, Vianello is cited by Hernàndez-Esteve as a foundational source for reconstructing a charge of plagiarism against Pacioli by Niccolò Tartaglia (HernàndezEsteve, 1994: 68).

Sangster considers the effort of Vianello as remarkable (Sangster, 2012: 100):

Despite all the efforts of the renowned Italian accounting researcher, Fabio Besta (1845-1922) and his students in the Venetian archives (see Vianello, 1896: 116), no handwritten text on accounting has ever been found that predates Pacioli's bookkeeping treatise other than a 5-page overview of bookkeeping in a manuscript written in Naples in 1458 by Benedetto Cotrugli. (Sangster et al., 2008: 112)

The same author has recently discovered a fifteenth-century treatise on DEB located in the National Library of Malta enforcing the thesis of Vianello, as explained further below (Sangster, 2014, 2015).

The contributions of Italian scholars of the late nineteenth century have certainly influenced the international historical research of a later period. First, Italians scholars provided the tools to carry out such research, as the primary sources were not available abroad. Second, they posed some of the main problems of historiography regarding Pacioli: the biography, the originality and the 
structure of the Tractatus, and the explanation for the emergence of DEB. Finally, contrary to what one might believe, a hagiographic tone was avoided in the narration of the historical figure of Pacioli. In some cases, indeed, the authors expressly criticized the Tractatus, as in the case of alleged plagiarism (based on a linguistic issue that only could be appreciated by those who know medieval Italian), a subject which non-Italian historians have continued to debate.

\section{Italian bookkeeping treatises after Pacioli}

The international debate on the main Italian bookkeeping treatises published after 1494, mainly revolves around four areas of research.

The first research area, which is also the oldest one, aims at providing an overview of works published in Italy in the sixteenth and seventeenth centuries. In doing so, authors in this area seek to show the development of accounting practice, its formalization, and its spread from Italy to other European countries. They briefly mention the biography and the main works of these writers of treatises, without providing a sustained discussion (Kheil, 1896; Volmer, 1896; Brown, 1905: 134137; Woolf, 1912: 120-123; Murray, 1930: 160-172; Peragallo, 1938: 54-73; Hatfield, 1943; Vlaemminck, 1956: 93-96; Kataoka, 1995).

The second research area, mainly developed during the second half of the twentieth century, focuses on the technical solutions of the DEB method as developed by post-Pacioli Italian scholars. Those solutions include accounting classification, trial balance, compound entries, Partimenti accounts and closing procedures (Littleton, 1928; Peragallo, 1956, 1971; Yamey, 1970, 1979, 1981; Lanero Fernández and Ortega Montes, 2006).

The third research area examines Benedetto Cotrugli and his work Della mercatura et del mercante perfetto, which was published in 1573 but completed in 1458; there was a manuscript copy in 1475 in Naples, which was rediscovered in the National Library of Malta. This work challenges Pacioli's book as being the oldest published essay on bookkeeping (Kheil, 1906; Jouanique, 1994, 1996; Yamey, 1994; Postma and Van der Helm, 1998; Van Der Helm and Postma, 2000).

In this respect, Sangster recently argued that in 1475 Marino de Raphaeli, a merchant, accepted a commission to teach DEB to Zuan de Domenego, a noble of Venice. De Raphaeli had to travel to Naples and make a copy of Benedetto Cotrugli's manuscript book. He then travelled with his copy to the Venetian Republic, where he proceeded to teach his pupil the art of DEB by dictation. According to Sangster, De Raphaeli presented de Domenego with his copy of Cotrugli's text. De Domenego then placed his manuscript copy of de Raphaeli's dictated bookkeeping manuscript at the back of the Cotrugli text, numbered the folios of both texts into one sequence, and then bound them together in one volume (Sangster, 2015: 9).

The fourth research area, also the most recent one, develops a critical interpretation of some of these works, and in particular of Jesuit Ludovico Flori's important work from 1600 (Yamey, 1985).

Within this context, it is possible to evaluate the dissemination and impact of major Italian contributions of this period on the topic under consideration. We are referring to Bonalumi (1880), Cerboni (1889), Alfieri (1891), Rigobon (1894), Bariola (1897) and Luchini (1898). When considering the first research area, Italian scholarship deeply influenced the international literature on accounting history.

Bonalumi (1880) is quoted by Volmer (1896: XV), Kheil (1896: 3; 1902: 14) and Vlaemminck (1956: 94), with respect to the Manzoni treatise published in 1540. Cerboni (1889) is quoted by Kheil (1896: 3, 123; 1902: 14), referring to the Pacioli, Casanova and Manzoni treatises, by Dumarchey (1914: 29) and Murray (1930: 165). Alfieri (1891) is quoted in Kheil (1896: 14), with reference to Manzoni's treatise, and Peragallo (1938: 60, 76). Rigobon (1894) is quoted by Penndorf when he dealt with Tagliente's work (1933: 70). 
In addition, international contributions to the literature examining technical improvements on the DEB method of the post-Pacioli era draw on Italian scholars from the late nineteenth century. Yamey cites Bonalumi (1880) when he studies the disappearance of the usage of the Partimenti account (Yamey, 1981: 3). Cerboni is cited by Chatfield (1968: 417) and by Yamey (1981: 7; 1985: 820), respectively, on the usage of the Partimenti account and Puglisi's treatise. Cerboni is cited by Zan (1994: 281), Kataoka (1995) and Quattrone (2004: 664) with reference to the work of Ludovico Flori. Alfieri (1891) is cited by Van der Helm and Postma (2000: 176), again on Manzoni and Pacioli with respect to compounding simple entries.

When considering the third research area - Cotrugli's work before the Tractatus - Kheil extensively drew from Alfieri's work (1891), when he focused on Cotrugli's biography and writing (Kheil, 1906: 22). Yamey cites Vianello when the latter had doubt on Cotrugli's description of DEB (Yamey, 1994: 47).

The contributions of Italian accounting historians in the nineteenth century brought to the attention of the international historical community a series of printed works on bookkeeping not easily available in the European libraries of the late nineteenth and early twentieth centuries. They also opened the debate on an issue - the evolution of the theoretical and applied aspects of DEB over the centuries - that, in the early nineteenth century, was virtually unknown. Finally, they influenced the studies of the later period on some of these treatises, which were written in ancient Italian and sometimes difficult to decipher for printing.

\section{Discussion}

After the unification of Italy and until the end of the nineteenth century, the professional and scientific communities saw bookkeeping as a primarily "technical" subject, secondary to "scientific" subjects. Bookkeeping was only taught in vocational schools and in state commercial and technical institutes. None of these were institutions of higher education (Ferraris Franceschi, 2012a, 2012b).

This was a pressing issue, particularly for professionals, whose daily job involved interactions with colleagues holding a university degree such as lawyers, engineers and architects. Moreover, in many cases, those professional figures illegitimately appropriated functions that, in their nature, fell within the domain of bookkeepers' competence (Coronella et al., 2015). Thanks to many protests carried out by scholars and professionals alike, finally, in 1906, commercial studies were recognized as university subjects, and the bookkeeper was given professional status. Accountancy in these years entered a period of great development and social success, both from the professional point of view and as a research subject (Amaduzzi, 2004: 271-287; Coronella, 2014: 324-344). In particular, during the last few years of the nineteenth century, we notice the following:

- the organization of the first national bookkeeping conferences (the first one was held in 1879);

- the creation, on a voluntary basis, of bookkeepers' associations (the first one was created in 1879);

- a request for the inclusion of bookkeeping among university subjects (this was possible thanks to the momentum created by the first national congress);

- the promotion of editorial efforts by creating specialized academic journals (the first one dates from 1875), and by publishing complete bookkeeping treatises (the first one dates from 1883-1889), commercial lexicons (the first one dates from 1872-1873) and specialized encyclopaedias (the first one dates from 1891-1905);

- the development of the earliest systematic historical studies of bookkeeping. 
It is not surprising that the earliest historical studies of bookkeeping were developed then. In effect, the attention given to bookkeeping history is a clear sign of the degree of maturity that the discipline had reached at that time. Besides deepening systematic studies, scholars started to investigate the origin and developments of this subject. They did not do this just out of curiosity. Their effort was instrumental in establishing bookkeeping as a legitimate subject. It is not coincidental that, around the same time, we see the emergence of "scientific" bookkeeping and Besta's endorsement of the "historical method" as a foundation for study and research.

To properly understand its relevance, this issue must be seen in light of the discipline's development from a scientific and professional point of view, and its increasing popularity: bookkeeping stopped being a subject for the few. Instead it attracted a growing interest, even in terms of enrolment in vocational schools and high schools (Ferraris Franceschi, 2012a, 2012b). Bookkeepers either as professors and professionals, or both - have discussed at length the history of bookkeeping in order to show that bookkeeping and the job of the bookkeeper had ancient, thus "noble", origins. This was necessary for the discipline to gain more recognition regarding what pertains to academic research and professionalism. Let us now consider the most important works.

The importance of Luchini's work, dating to 1869 , is strongly emphasized in international literature on accounting history. Luchini's booklet is considered to be a turning point in the European history of accounting, especially with reference to the introduction of Luca Pacioli's life and writings. Pacioli was unknown to accountants at that time. It was, therefore, a revelation to them to learn that an illustrious predecessor had published before 1500 a book which treated, though not under that name, the theory of DEB (Stevelinck, 1986: 3; Beard, 1996: 138; Hernàndez-Esteve, 2006: 199).

Richardson cites Luchini's paper as an example of how to create a "myth" in the evolution of accounting, making Pacioli a national hero:

Without doubt, the iconic accounting hero is Friar Luca Pacioli, a Franciscan monk, who wrote a book on mathematics in 1494 that included a chapter on double-entry bookkeeping as an illustration of practical applications of mathematics. The book was "discovered" in $1869 \ldots$ and reintroduced into academic circles, sparking an industry tracing the diffusion of double-entry bookkeeping techniques from Pacioli through time and across borders. (Richardson, 2008: 257)

Regarding Cerboni (1889), Napier wrote: "For example, Giuseppe Cerboni ... underpinned his theoretical expositions (for example, Cerboni 1886) with a chronological survey of Italian writings on bookkeeping and accounting, and surviving Italian accounting records (Cerboni 1889)" (Napier, 2009: 34). Zan highlights the pioneering efforts of Bariola (and Cerboni): "Indeed accounting historiography is rather old, and already in the end of nineteenth century there were work[s] already dedicated to build up a history of accounting: cf. for Italy Cerboni, 1889; Bariola, 1897" (Zan, 2005: 484). At the same time, Zan remarks on the national bias of Bariola's research:

Bariola concerns himself exclusively with the history of Italian accounting ... the contributions of those Italian historians who adopt a broad focus on the "modern" and "contemporary" ages ... are infused with a nationalist - and even chauvinist - rhetoric ... But then Bariola, for one, lived in the nationalistic period following the unification of the country. (Zan, 1994: 258, 270)

\section{Conclusions}

Historiography is concerned with the problems of object and method of accounting history, as it is concretely studied in various countries and periods of time. In this respect, the Italian tradition of research can be considered of particular interest for the international community of accounting 
historians for many reasons. This is probably due to a kind of double "competitive advantage" of Italian scholars. First, they can tap into the abundance of archival materials about crucial events, such as the origins of DEB, the life and work of Luca Pacioli, or the publication of a treatise without significant logistical difficulties. Second, Italian authors are able to understand the linguistic nuances present in the archival materials and printed manuals; all, of course, written in ancient Italian.

Parts of the literature on Italian accounting history have received focused attention in papers published in recent international refereed journals (Sargiacomo et al., 2012; Antonelli and D'Alessio, 2014; Antonelli and Sargiacomo, 2015; Coronella et al., 2015), but some are still unknown to the English-speaking community of scholars. In order to fill this gap in awareness of the existence of this material, this article focused on works written on accounting history in the second half of the nineteenth century, that is, just after Italian unification. Consistent with this aim, we have identified and delimited the universe of accounting history publications to be taken into account, by referring to some published bibliographic reviews and other sources. We have thus identified and consulted 56 books and pamphlets and 95 articles. The census publications were then classified by content and date of printing, aided by Google Scholar and other sites that make available the text of books and articles (including https://books.google.it/, http:// gallica.bnf.fr/ and https://archive.org/). Also, after visiting some Italian libraries, we were able to reconstruct the quotations of Italian publications of the late nineteenth century by the international community of accounting historians. These citations were classified on the basis of the language spoken by the authors (English, Latin languages, German) and the historical problems to which they referred (accounting in the Roman Empire, the origins of DEB, Luca Pacioli, the main treatises on bookkeeping). We then analysed in detail the above-mentioned historical issues, outlining what were the main concepts and guidelines of international studies, placing these concepts and guidelines in parallel with the most quoted (at an international level) Italian publications of the late nineteenth century.

The variety of the historical research conducted in Italy in the second half of the nineteenth century (and the vast number of individuals involved in this research) emerges clearly, particularly if we consider that few systematic historical works were published in Europe before or during the same period (Foster, 1852; Jäger, 1874, 1876; Voigt, 1887; Kheil, 1896; Sieveking, 1898). Indeed, works by foreign scholars at that time were well known to Italian researchers. Some of those, in fact, were regularly cited, at least in more systematic monographic works (Bonalumi, 1880; Alfieri, 1891; Rossi, 1896; Vianello, 1896; Bariola, 1897).

The contributions coming from Italy appear particularly important for several reasons. First, they represent the first body of studies that deals in a systematic way with accounting's past, in Italy and abroad, inventing a literary genre - the narrative of the accounting history - that did not exist before. Secondly, these studies involve a wide network of individuals: academics, practitioners, office bearers and historians. Third, some monographs on particularly relevant topics emerge from the panorama of the Italian works considered here.

When Italian scholars have written about accounting history, they have mainly focused on the Roman Empire and the Middle Ages, with particular reference to DEB, Luca Pacioli, and the bookkeeping treatises after Pacioli. They reveal the important role played by Italy in the fundamental stages of the development of accounting, interrupted only during the "dark ages" (mid-1600s to the late 1800 s), by political submission and foreign intervention, being the lowest point of an otherwise bright history (as stated in Zan, 1994: 270). As a matter of fact, the Italian authors studied laid the foundations of later studies, nowadays known as Traditional Accounting History (Miller et al., 1991; Carnegie and Napier, 1996; Napier, 2006). 
Finally, primary sources were used substantially; indeed, the publications considered stand out because of the abundance of documents, records and artefacts usually displayed. This abundance gave them a useful function for those who, in successive stages, devoted themselves to the examination of the same topics.

The contributions of this article to the accounting history literature are many. First, it expands knowledge of the histories of accounting that appeared in Italy in the late nineteenth century. In particular, it deepens understanding of the contents of the main works of accounting history published in that period, which other scholars before us have already referred to, but only by quoting (Zan, 1994; Beard, 1996; Mattessich, 2003; Coronella et al., 2015) or by including some other aspects in their statistical analysis (Antonelli and D'Alessio, 2011, 2014). Second, the article shows that the Italian historical literature of the late nineteenth century focused, set and, in part, solved some key problems of accounting history, some of which remain a concern to this day. Finally, we point out how the historical literature here examined, although in Italian and intended for a domestic audience, had many citations in books and articles of the community of accounting historians around the world. In particular, it has been shown that the wide and prolonged dissemination of such historical works is due to a series of specific contributions made by those works, such as the reproduction of original documents (made available to all readers, even on an international scale), the collection of information hitherto unpublished on the life and works of the main protagonists of the Middle Ages, the setting of problems such as "What is DEB in an historical perspective?", "What are the origins of DEB?", and so on.

This research has some limitations. First, it has offered only a glimpse into the whole Italian historical literature of the period considered, without the possibility of going into depth on each contribution. Second, it is limited to the late nineteenth century. Finally, it did not examine two possible circumstances that may have motivated such great interest in historical studies during this time. On one hand, it could be investigated whether the affirmation of the first studies in Italian accounting theory conducted at the end of the nineteenth century have found solid support in the narratives of accounting's past (Gomes, 2008). On the other hand, one might investigate how the efforts made by practitioners in relation to historical research have been driven by the intention to legitimize the accounting profession in the eyes of public opinion, the scientific community, the newly born middle class and business people (Previts et al., 1990b).

The article leaves opportunities for further investigations. Large-scale reconstruction of the research on pre-1980 accounting history is just starting. Little is known, in fact, about historical research conducted in countries having longstanding traditions of such scholarship, such as Germany, France, Britain and the United States. We do not know if a tradition of historical research, dating back to before World War II, or even the late nineteenth century, has been present in other countries (for example, Spain, Portugal and Belgium). And this is to say nothing of non-European countries such as Japan. In addition, historiographical research on the communities of accounting historians of different countries and time periods will help to give a more complete vision of the events and can be addressed to understand and explain similarities and differences, according to the scheme of Comparative International Accounting History (Carnegie and Napier, 1996, 2002; Carnegie and Rodrigues, 2007).

\section{Acknowledgements}

The authors thank the anonymous reviewers for their contribution to the improvement of the paper.

\section{Funding}

This research received no specific grant from any funding agency in the public, commercial, or not-for-profit sectors. 


\section{Notes}

1. Among others, these volumes are available: Bariola (1897): https://archive.org/details/storiadellaragio01bari; Luchini (1898): https://archive.org/details/storiadellaragi00luchgoog; Saporetti (1898): https://archive.org/details/fralucapacioloo00sapogoog; and Vianello (1896): https://archive.org/details/ lucapaciolonell00viangoog.

2. We cannot analyse all the literature concerning Pacioli's life and writings. Thus, we review only the works quoting the Italian scholars examined in the paper.

\section{References}

\section{Italian historical literature}

Alfieri V (1891) La partita doppia applicata alle scritture delle antiche aziende mercantili veneziane. Torino: G.B. Paravia e Comp.

Alfieri V (1896) L'amministrazione economica dell'antico comune di Perugia. Perugia: Unione Tipografica Cooperativa.

Anonymous (1880) Illustri cultori della ragioneria. Luca Paciolo, Francesco Marchi, Giuseppe Cerboni. Novara: Tipografia della Rivista di Contabilità.

Anonymous (1884) Cenni storici sull 'Accademia dei Ragionieri in Bologna. Bologna: Monti.

Anonymous (1888) L'Accademia dei Ragionieri di Bologna. Cenni storici, statuti, memorie. Bologna: Tip. Soc. Azzoguidi.

Appiani F (1893) Filippo Parmetler. I suoi tempi e le sue opere. Cenni biografici. Torino: Tip. Camilla \& Bertolero.

Baccarini G (1837) Memorie storiche de' registri economici. Ravenna: Tipografia Roveri.

Bachi R (1896) I bilanci, le scritture e i rendiconti nella monarchia piemontese nel secolo XVIII. Torino: Tip. Foa \& Sacerdote.

Bachi R (1899) La partita doppia applicata alla contabilità di stato da Simon Stevin di Bruges. Milano: Stabilimento Tipografico Attilio Boriglione.

Barduzzi L (1883) Sulla storia della ragioneria. Note. Treviglio: Tip. Sociale.

Bariola P (1897) Storia della ragioneria italiana, premiata al Concorso della Società Storica Lombarda. Milano: Tip. Ambrosiana di Cavalli, Salmini \& C.

Bonalumi FA (1878) Storia della genesi e dello svolgimento del pensiero logismografico. Sanremo: Stab. Ligure Bianchieri.

Bonalumi FA (1880) Sullo svolgimento del pensiero computistico in Italia. Cenni storico-bibliografici. Novara: Tipografia Rivista di Contabilità.

Bosellini L (1864) Dell'arte del ragioniere. Modena: Tip. Soliani.

Brambilla G (1894) L'amministrazione e la ragioneria nella China antica. Milano: Stab. Tip. Boriglione.

Brambilla G (1896) Saggio di storia della ragioneria presso i popoli antichi. Milano: Stab. Tip. Boriglione.

Brambilla G (1898) Saggi critici di storia della ragioneria. Gli albori della ragioneria italiana: il secolo XIX. Milano: Stab. Tip. Boriglione.

Brandaglia G (1882) Luca Paciolo considerato come ragioniere. Lezione tenuta nella R. Scuola Superiore di Commercio in Venezia il 30 maggio 1882. Novara: Tip. Rivista di Contabilità.

Campi V (1879) Il ragioniere. Appunti storici. Roma: Stamperia Reale.

Campi V (1887) Il ragioniere sotto la Repubblica Romana e sotto l'impero. Roma: Tip. Naz. Reggiani.

Capparozzo G (1880) Sulla origine della scrittura doppia. Vicenza: Tip. Reale Burato.

Cerboni G (1886) La ragioneria scientifica e le sue relazioni con le discipline amministrative e sociali, Volume I, Prolegomeni, Roma: Ermanno Loescher \& C.

Cerboni G (1889) Elenco cronologico delle opere di computisteria e ragioneria venute alla luce in Italia dal 1202 al 1888. Roma: Tip. Naz. Reggiani.

Corradini M (1889) Origini e sviluppo degli ordinamenti contabili e finanziari nella monarchia di Savoia. Modena: Tip. Moneti.

Cuccoli G (1881) Appunti critici sul movimento ascendente del pensiero computistico desunto dalle ultime disputazioni degli scrittori francesi. Roma: Tip. Botta. 
Dabbene A (1893) Ordinamento contabile della Tavola di Palermo. Palermo: Stab. Tip. Virzi.

Gentile A (1878) Cenni storici intorno alle vicende della contabilità dell'amministrazione del Regno d'Italia dal 1860. Como: Ostinelli.

Ghidiglia C (1895) La ragioneria nel passato, nel presente e nell'avvenire. Conferenza tenuta agli allievi del terzo e quarto corso del R. Istituto tecnico di Assisi il 22 giugno 1895. Assisi: Tip. Froebel.

Giardina P (1885) Della limitazione delle spese presso gli antichi e del bilancio di previsione negli stati moderni. Modica: Tip. Avolio.

Giardina P (1887) Organismi finanziari e contabili in Sicilia. Reggio Calabria: Stab. Tip. Ceruso.

Gitti V (1877) Gli scrittori classici della partita doppia. Torino: Tip. Camilla \& Bertolero.

Gitti V (1878a) Sulla storia della ragioneria. Discorso letto alla società dei ragionieri di Torino. Torino: Tip. Camilla \& Bertolero.

Gitti V (1878b) Luca Pacioli. Trattato de' computi e delle scritture. Torino: Tip. Camilla \& Bertolero.

Gitti V (1882) Gerolamo Cardano. De ratione librorum tractandorum. Del modo di tenere i libri. Torino: Tip. Camilla \& Bertolero.

Gitti V (1884) Il passato e l'avvenire della Ragioneria. Discorso letto il 21 aprile 1884 nel R. Istituto Tecnico Germano Sommelier in Torino. Torino: Tip. Camilla \& Bertolero.

Lanfranchi G (1891) Le origini della partita doppia secondo le più recenti indagini. Ferrara: Tip. Sociale.

Lanfranchi G (1897) Edmond Degrange (père) iniziatore delle scritture riassuntive ed inventore del giornalmastro. Ferrara: Tipografia Sociale.

Luchini E (1869) Sulle origini storiche della professione di ragioniere. Memoria. Bollettino degli Atti dell'Accademia dei Ragionieri in Milano 1(1): 51-72.

Luchini E (1881) Sulle origini storiche della professione di ragioniere. Memoria. Milano: Tip. Giuliani.

Luchini E (1898) Storia della ragioneria italiana. In: Massa G (ed) La professione del ragioniere. Milano: Amministrazione "Il Ragioniere", pp.1-140.

Mannarino S (1891) Cenni storici sulla importanza della ragioneria in generale, dai tempi antichi fino ai giorni nostri. Catanzaro: Tip. Calio.

Ministero del Tesoro - Ragioneria Generale dello Stato (1878) Genesi e sviluppo della logismografia. Cenni storici da servire per l'esposizione dei lavori logismografici alla Mostra Universale di Parigi nell'anno 1878. Roma: Tipografia Elzeviriana.

Mondini E (1882) La ragioneria. Storia e considerazioni da F. Marchi alla chiusura del 2 congresso. Como: Ostinelli.

Montani C (1886) Gli organismi finanziari della Repubblica di Firenze. Contabilità di stato. Rimini: Tip. Renzetti.

Passerini P (1875) Origine della teoria sul sistema della scrittura a partita doppia. Antichi scrittori italiani che trattarono tale materia e Francesco Marchi autore dell'opera I cinquecontisti. Considerazioni. Torino: Ditta Paravia.

Perugini R (1888) Cenno sulla ragioneria fino a Paciolo (1494). Macerata: Tip. Economica.

Rigobon P (1892a) La contabilità di Stato nella Repubblica di Firenze e nel Granducato di Toscana. Girgenti: Stamperia Provinciale-Commerciale di Salvatore Montes.

Rigobon P (1892b) Di un contributo del prof. Alfieri Vittorio alla storia della ragioneria e di Benedetto Cotrugli primo espositore della partita doppia. Milano: Tipografia Golio.

Rigobon P (1894) Di Giovanni Antonio Tagliente veneziano e delle sue opere di ragioneria. Il ragioniere. Serie II 10(1): 21-35.

Rossi G (1882) L'unificazione della contabilità di Stato considerata nel suo presente periodo evolutivo. Reggio nell'Emilia: Stabilimento Tipo-Litografico degli Artigianelli.

Rossi G (1896) La computisteria dei Romani e l'invenzione della scrittura doppia. A proposito di un'opinione dello storico G. B. Niebuhr. Roma: Società Editrice Dante Alighieri.

Salvagnini O (1879) Cinquecontisti e razionalisti. Argomenti di studio proposti ai cultori della partita doppia. Firenze: Tipografia Fratelli Bocca.

Salvatori A (1890) La doppia scrittura commerciale dinanzi alla contabilità di stato in Inghilterra negli anni dal 1828 al 1831. Studio. Roma: Tipografia Eredi Botta.

Saporetti F (1898) Frà Luca Pacioli. Origine e sviluppo della partita doppia. Livorno: Stab. Tip. Belforte \& C. Stella A (1889) Il servizio di cassa nella antica Repubblica Veneta. Studio. Venezia: Visentini. 
Tavernari C (1891) Cenni storico-amministrativi sulla Congregazione di carità di Modena, con particolare riguardo all'ospedale congregazionale. Modena: Tipografia Bassi \& Debri.

Vianello V (1896) Luca Paciolo nella storia della ragioneria, con documenti inediti. Messina: Libreria Trimarchi.

Vitale F (1896) Storia della ragioneria in Italia dalle origini ai nostri tempi. Aversa: Tip. Fabozzi.

Zambonini G (1889) Paciolo e Cardano. Modena: Tip. Felici.

Zambonini G (1894) I trapeziti o banchieri dell'antica Grecia. Saggio storico. Modena: Tip. Alfonso Moneti.

\section{Other references}

Aho J (2012) Confession and Bookkeeping. The Religious, Moral and Rhetorical Roots of Modern Accounting. New York: University of New York Press.

Amaduzzi A (2004) Storia della ragioneria. Percorsi di ricerca tra aziende e contabilità, dottrine e professioni. Milano: Giuffrè.

Amzalak MB (1943) A contabilidade e a história económica. Porto: Tip. Costa Corregal.

Antonelli V and D'Alessio R (2011) Summa DB. A research note about an Italian accounting history database. Accounting History 16(4): 459-473.

Antonelli V and D'Alessio R (2014) Accounting history as a local discipline: The case of the Italian-speaking literature (1869-2008). The Accounting Historians Journal 41(1): 77-112.

Antonelli V and Sargiacomo M (2015) Alberto Ceccherelli (1885-1958): Pioneer in the history of accounting practice and leader in international dissemination. Accounting History Review 25(2): 121-144.

Arena G and Gambino SA (2008) La ragioneria in Italia. Bibliografia di autori minori, 1867-1927. Messina: Società Messinese di Storia Patria.

Beard V (1996) Book review: Amaduzzi Antonio and Cavazzoni Gianfranco (1996), Biblioteca storica di Ragioneria ed Economia Aziendale. The Accounting Historians Journal 23(1): 137-142.

Besta F (1909-1916) La ragioneria. Seconda edizione riveduta ed ampliata colo concorso dei professori Vittorio Alfieri, Carlo Ghidiglia, Pietro Rigobon. Parte prima. Milano: Vallardi.

Boursy AV (1943) The name of Paciolo. The Accounting Review 18(3): 205-209.

Bresnahan Menning C (1993) Charity and State in Late Renaissance Italy: The Monte di Pietà of Florence. New York: Cornell University Press.

Brown R (1905) A History of Accounting and Accountants. Edinburgh: Blackwood.

Bunson M (2013) Encyclopedia of the Roman Empire. New York: Facts on Files.

Burchell S, Clubb C, Hopwood AG and Hughes J (1980) The roles of accounting in organizations and society. Accounting, Organizations and Society 5(1): 5-27.

Carmona S (2006) Performance reviews, the impact of accounting research, and the role of publication forms. Advances in Accounting 22(2): 241-267.

Carmona S (2007) The history of management accounting in France, Italy, Portugal and Spain. In: Chapman CS, Hopwood AG and Shields MD (eds) Handbook of Management Accounting Research, Vol. 2. Oxford: Elsevier, pp.905-922.

Carmona S and Zan L (2002) Special section. Mapping variety in the history of accounting and management practices. European Accounting Review 11(2): 291-304.

Carnegie GD (2014a) Historiography for accounting: Methodological contributions, contributors and thought patterns from 1983 to 2012. Accounting, Auditing \& Accountability Journal 27(4): 715-755.

Carnegie GD (2014b) The present and future of accounting history. Accounting, Auditing \& Accountability Journal 27(8): 1241-1249.

Carnegie GD and Napier CJ (1996) Critical and interpretive histories: Insights into accounting's present and future through its past. Accounting, Auditing \& Accountability Journal 9(3): 7-39.

Carnegie GD and Napier CJ (2002) Exploring comparative international accounting history. Accounting, Auditing \& Accountability Journal 15(5): 689-718.

Carnegie GD and Napier CJ (2012) Accounting's past, present and future: The unifying power of history. Accounting, Auditing \& Accountability Journal 25(2): 328-369.

Carnegie GD and Rodrigues LL (2007) Exploring the dimensions of the international accounting history community. Accounting History 12(3): 441-464. 
Carruthers BG and Espeland WN (1991) Accounting for rationality: Double-entry bookkeeping and the rhetoric of economic rationality. American Journal of Sociology 97(1): 31-69.

Chapman CS, Cooper D and Miller PB (2009) Accounting, Organizations, and Institutions: Essays in Honour of Anthony Hopwood. Oxford: Oxford University Press.

Chatfield M (1968) Contemporary Studies in the Evolution of Accounting Thought. Belmont: Dickenson Publishing Company.

Chatfield M (1996) Rome (509 a.c.-a.d. 487). In: Chatfield M (ed) The History of Accounting (RLE Accounting): An International Encyclopedia. New York: Routledge, pp.505-507.

Chiapello E (2007) Accounting and the birth of the notion of capitalism. Critical Perspectives on Accounting 18(3): 263-296.

Cinquini L, Marelli A and Tenucci A (2008) An analysis of patterns in accounting history research in Italy 1990-2004. The Accounting Historians Journal 35(1): 1-48.

Coronella S (2014) Storia della ragioneria italiana. Epoche, uomini e idee. Milano: FrancoAngeli.

Coronella S, Sargiacomo M and Walker SP (2015) Unification and dual closure in the Italian accountancy profession, 1861-1906. European Accounting Review 24(1): 167-197.

Davies ME and Swain H (2010) Aspects of Roman History. 82 BC-14 AD. A Source-based Approach. London and New York: Routledge.

De Roover R (1937) Aux origines d'une technique intellectuelle. La formation et l'extension de la comptabilité à partie double. Annales d'Histoire Economique et Sociale 9(45): 270-298.

De Roover R (1943) Early accounting problems of foreign exchange. The Accounting Review 18(2): 381-407.

De Roover R (1944) Paciolo or Pacioli. The Accounting Review 19(4): 68-69.

De Roover R (1955) New perspectives on the history of accounting. The Accounting Review 30(4): 405-420.

De Roover R (1956) The development of accounting prior to Luca Pacioli according to the account-books of medieval merchants. In: Littleton AC and Yamey BS (eds) Studies in the History of Accounting. Homewood IL: Irwin, pp.114-174.

De Roover R (1958) The story of the Alberti company of Florence, 1302-1348, as revealed in its account books. Business History Review 32(1): 14-59.

De Ste Croix GEM (1956) Greek and Roman accounting. In: Littleton AC and Yamey BS (eds) Studies in the History of Accounting. Homewood IL: Irwin, pp.14-74.

Doren A (1934) Italienische Wirtschaftsgeschichte. Jena: G. Fischer.

Dumarchey J (1914) Théorie positive de la comptabilité. Lyon: Rey.

Dupont A (1925) La partie double avant Paciolo: les origines et le dévelopement de la méthode. Paris: Société de la Comptabilité de France.

Eddie IA and Murphy BJ (1985) The contribution of double entry bookkeeping in the development of capitalism: A study of the debate. Accounting History Newsletter 10 (Winter): 35-47.

Edwards JR (2009) Subjects, sources and dissemination. In: Edwards JR and Walker SP (eds) The Routledge Companion to Accounting History. Abingdon: Routledge, pp.11-29.

Ferraris Franceschi R (2012a) La diffusione e lo sviluppo delle discipline ragioneristiche nell'Italia unita: gli Istituti tecnici e le Scuole professionali. Rivista Italiana di Ragioneria e di Economia Aziendale 112(9-10): 446-463.

Ferraris Franceschi R (2012b) La fondazione delle Scuole superiori di commercio: il rilevante contributo allo sviluppo delle conoscenze ed alla formazione dei giovani nell'area ragioneristica e commerciale. Rivista Italiana di Ragioneria e di Economia Aziendale 112(11-12): 550-566.

Filios VP (1984) The transition of systematic accounting from ancient to Byzantine Greece. In: Antoni T (ed) Fourth International Congress of the History of Accountancy: Congress Proceedings. Pisa: Ets editrice, pp.171-191.

Foster BF (1852) The Origin and Progress of Bookkeeping. London: C.H. Law.

Funnell WN (2001) Distortions of history, accounting and the paradox of Werner Sombart. Abacus 37(1): $55-78$.

Gaffikin M (2011) What is (accounting) history? Accounting History 16(3): 235-251.

Galassi G (1996) Antoni Tito. In: Chatfield M and Vangermeesch R (eds) The History of Accounting (RLE Accounting). An International Encylopedia. New York: Garland, p.41. 
Galassi G and Mattessich R (2004) Italian accounting research in the first half of the twentieth century. Review of Accounting and Finance 3(2): 62-83.

Garner SP (1976) The Melis testimonial. The Accounting Historians Journal 3(1): 11-14.

Geijsbeek JB (1914) Ancient Double-Entry Bookkeeping: Lucas Pacioli's Treatise. Denver: by the author.

Giannessi E (1964) Rassegna bibliografica. Appendice. Pisa: Cursi.

Glautier MWE (1972) A study in the development of accounting in Roman times. Revue internationale des droits de l'antiquité 19(4): 311-343.

Gleeson-White J (2012) Double Entry: How the Merchants of Venice created Modern Finance. London: Norton.

Gomberg L (1912) L'économologique (science comptable) et son histoire. Genéve: Société Générale d'Imprimerie.

Gomberg L (1929) Histoire critique de la théorie des comptes. Genéve: chez l'Auteur.

Gomes D (2008) The interplay of conceptions of accounting and schools of thought in accounting history. Accounting History 13(4): 479-509.

Gomes D, Carnegie GD, Napier CJ, Parker LD and West B (2011) Does accounting history matter? Accounting History 16(4): 389-402.

Green K (1990) The Archaeology of Roman Economy. Berkeley: University of California Press.

Green WL (1930) History and Survey of Accountancy. New York: Standard Text Press.

Hatfield HR (1924) An historical defense of bookkeeping. Journal of Accountancy 37(4): 241-253.

Hatfield HR (1943) Neither Pietra nor Flori. Journal of Accountancy 56(2): 165-170.

Hernàndez Esteve E (1981) Castilian Laws of the Lower Middle Ages and Beginning of the Renaissance Related to Merchants' Accounting and Account Books. Valladolid: Universidad.

Hernàndez-Esteve E (1994) Luca Pacioli's treatise De Computis et Scripturis. A composite or a unified work? Accounting, Business \& Financial History 4(1): 67-82.

Hernàndez-Esteve E (1997) Historia de la contabilidad: Pasado rumbo al futuro. Revista de Contabilidade e Comercio 54(216): 611-690.

Hernàndez-Esteve E (2006) La historia de la contabilidad: una disciplina en auge. Revista international legis de contabilidad e auditoria 1: 191-213.

Hopwood AG (1983) On trying to study accounting in the context in which it operates. Accounting, Organizations and Society 8(2-3): 287-305.

Hopwood AG (1987) The archaeology of accounting systems. Accounting, Organizations and Society 12(2): 207-234.

Jacobsen LE (1964) The ancient Inca empire of Peru and the double entry accounting concept. Journal of Accounting Research 2(2): 221-228.

Jäger EL (1874) Beiträge zur Geschichte der Doppelbuchhaltung. Stuttgart: Kröner.

Jäger EL (1876) Lucas Paccioli und Simon Stevin, nebst einigen jüngeren Schriftstellern über Buchhaltung. Skizzen zur Geschichte der kaufmännischen, staatlichen und landwirtschaftlichen Buchführung. Stuttgart: Kröner.

Jäger EL (1889) Lucas Paccioli und Simon Stevin. Supplement zu den zwei Hauptwerken über die Geschichte der Buchhaltung. Stuttgart: Liesming und Comp.

Jouanique P (1968) Le "Codex Accepti et Expensi" chez Cicéron. Revue Historique de Droit Français et Etranger 46(1) 5-31.

Jouanique P (1994) Benedetto Cotrugli reencontrado. Tecnica Contable 46: 205-223.

Jouanique P (1996) Three medieval merchants: Francesco di Marco Datini, Jacques Coeur and Benedetto Cotrugli. Accounting, Business \& Financial History 6(3): 261-275.

Kataoka Y (1995) The relationship between the bookkeeping systems of Pacioli and Schweicker. In: Tsuji A and Garner P (eds) Studies in Accounting History: Tradition and Innovation for the Twenty-first Century. Westport: Greenwood Press, pp.158-168.

Kats P (1929) Early history of bookkeeping by double entry. Journal of Accountancy 47(3): 203-210.

Kats P (1930) A surmise regarding the origin of bookkeeping by double entry. The Accounting Review 5(4): 311-316.

Kheil CP (1896) Ueber einige ältere bearbeitungen des buchhaltungs-tractates von Pacioli. Ein beitrag zur geschichte der buchhaltung. Prag: Bursik \& Kohout. 
Kheil CP (1902) Historia de la contabilidad: versión al castellano de las obra alemana de Karl Peter Kheil. Alicante: Imprenta de Moscat y Orate.

Kheil CP (1906) Benedetto Cotrugli Raugeo: Ein Beitrag zur Geschichte der Buchhaltung. Wien: Mantzche K.U.K. Hut Verlang und Universitat Buchandlung.

Lane FC (1944) Andrea Barbarigo, Merchant of Venice, 1418-1449. Baltimore: John Hopkins University Press,

Lane FC (1945) Venture accounting in medieval business management. Bulletin of the Business Historical Society 19(5): 164-173.

Lane FC (1977) Bookkeeping and resident merchants. Journal of European Economic History 1(1): 178-191.

Lanero Fernández J and Ortega Montes E (2006) Algunas consideraciones historiográficas sobre la lógica de la Partida Doble y la clasificación de Cuentas. Pecunia 2: 65-78.

Laurence R (2012) Roman Archaeology for Historians. Abingdon: Routledge.

Lee GA (1973) The development of Italian bookkeeping, 1211-1300. Abacus 9(2): 137-155.

Lee GA (1977) The coming of age of double entry: The Giovanni Farolfi ledger of 1299-1300. The Accounting Historians Journal 4(1): 79-95.

Littleton AC (1928) The evolution of the journal entry. The Accounting Review 3(4): 383-396.

Littleton AC (1933) Accounting Evolution to 1900. New York: American Institute Publishing Co. Inc.

Lopes de Sà A (1995) A hypothesis on Paciolo's learning of double entries. In: Special World Conference to Celebrate Frà Luca Pacioli. Milano: Ipsoa, pp.97-101.

Lopes de Sà A (2004) Luca Pacioli: un mestre do Renascimento. Brasìlia: Fundaçao Brasileira de Contabilidade.

Lukka K and Kasanen E (1996) Is accounting a global or a local discipline? Evidence from major research journals. Accounting, Organizations, and Society 21(7-8): 755-773.

Macve RH (1985) Some glosses on Greek and Roman accounting. In: Antoni T (ed) Fourth International Congress of the History of Accountancy. Pisa: ETS, pp.409-432.

Macve RH (2002) Insights to be gained from the study of ancient accounting history: Some reflections on the new edition of Finley's The Ancient Economy. European Accounting Review 11(2): 453-472.

Martinelli A (1974) The origination and evolution of double-entry book-keeping to 1440. Unpublished doctoral thesis. Ann Arbor MI: University Microfilms.

Martinelli A (1977) Notes on the origin of double entry bookkeeping. Abacus 13(1): 3-27.

Martinelli A (1983) The ledger of Cristianus Lomellinus and Dominicus De Garibaldo, stewards of the city of Genoa (1340-41). Abacus 19(2): 83-118.

Massa G (1912) Trattato completo di ragioneria. Vol. XII. Storia e bibliografia. Milano: Monitore dei Ragionieri.

Mattessich R (1989) Accounting and the input-output principle in the prehistoric and ancient world. Abacus 25(2): 74-84.

Mattessich R (2003) Accounting research and researchers of the nineteenth century and the beginning of the twentieth century: An international survey of authors, ideas and publications. Accounting, Business \& Financial History 13(2): 125-170.

Mattessich R (2008) Two Hundred Years of Accounting Research. An International Survey of Personalities, Ideas and Publications. Abingdon: Routledge.

McCarthy P, Sangster A and Stoner G (2008) Pacioli and humanism: Pitching the text in Summa Arithmetica. Accounting History 13(2): 183-206.

Miller P, Hopper T and Laughlin R (1991) The new accounting history: An introduction. Accounting, Organizations and Society 16(5): 395-403.

Mills GT (1994) Early accounting in northern Italy: The role of commercial development and the printing press in the expansion of double-entry from Genoa, Florence and Venice. The Accounting Historians Journal 21(1): 81-96.

Minaud G (2005) La comptabilité à Rome. Lausanne: Presses polytechniques et universitaires romande.

Morison S (1933) Fra Luca Pacioli of Borgo San Sepolcro. New York: The Grolier Club.

Morrisson C (2002) Coin usage and exchange rates in Badoer's Libro dei Conti. In: Talbot AM(ed) Dumbarton Oaks Papers, No. 55. Washington DC: Dumbarton Oaks Research Library and Collection, pp.217-244. 
Most KS (1972) Sombart propositions revised. The Accounting Review 47(4): 722-734.

Most KS (1976) How wrong was Sombart. The Accounting Historians Journal 3(2): 22-28.

Mousli M (2007) Luca Pacioli, père de la comptabilité? Alternatives économiques 260(7): 84-94.

Murray D (1930) Chapters in the History of Bookkeeping, Accountancy and Commercial Arithmetic. New York: Arno Press.

Napier CJ (2006) Accounts of change: 30 years of historical accounting research. Accounting, Organizations and Society 31(4): 445-507.

Napier CJ (2009) Historiography. In: Edwards JR and Walker SP (eds) The Routledge Companion to Accounting History. Abingdon: Routledge, pp.30-49.

Niebuhr BG (1820) M. Tullii Ciceronis orationum pfo M. Fontejo et pro C. rabiro fragmenta. T. Livvi libr. XCI fragmentum plenius et emendatius. L. Senecae fragmenta ex membranis bibliotechae vaticanae. Roma: Typografia De Romanis.

Nigam BL (1986) Bahi-Khata: The pre-Pacioli Indian double-entry system of bookkeeping. Abacus 22(2): $148-161$.

Nobes CW (1982) The Gallerani account book of 1305-1308. The Accounting Review 57(2): 303-310.

Oldroyd D (1995) The role of accounting in public expenditure and monetary policy in the first century AD Roman Empire. The Accounting Historians Journal 22(1): 117-129.

Oldroyd D and Dobie A (2009) Bookkeeping. In: Edwards JR and Walker SP (eds) The Routledge Companion to Accounting History. Abingdon: Routledge, pp.95-119.

Padroni G (1976) A profile of Melis. The Accounting Historians Journal 3(1): 15-17.

Pagliaini A (1901-5) Catalogo della Libreria Italiana dall'anno 1847 a tutto il 1899. Milano: ATLI.

Parker RH (1993) The scope of accounting history: A note. Abacus 29(1): 106-110.

Paton B and Easton Law J (2010) Communes and Despots in Medieval and Renaissance Italy. Burglington: Ashgate.

Penndorf B (1933) Abhandlung über die buchaltung 1494. Stuttgart: Poeschel Verlag.

Peragallo E (1938) Origin and Evolution of Double-Entry Bookkeeping: A Study of Italian Practice from the Fourteenth Century. New York: American Institute Publishing Company.

Peragallo E (1956) Origin of the trial balance. The Accounting Review 31(3): 389-394.

Peragallo E (1971) A commentary on Vigano's historical development of ledger balancing procedures, adjustments and financial statements during the fifteenth, sixteenth, and seventeenth centuries. The Accounting Review 46(3): 529-534.

Postma J and Van der Helm AJ (1998) Rewriting the history of accounting? Asia-Pacific Journal of Accounting 5(1): 166.

Previts GJ, Parker LD and Coffman EN (1990a) Accounting history: Definition and relevance. Abacus 26(1): $1-16$.

Previts GJ, Parker LD and Coffman EN (1990b) An accounting historiography: Subject matter and methodology. Abacus 26(2): 136-158.

Quattrone P (2004) Accounting for God: Accounting and accountability practices in the Society of Jesus (Italy, XVI-XVII centuries). Accounting, Organizations and Society 29(7): 647-683.

Rathbone D (1994) Accounting on a large estate in Roman Egypt. In: Parker RH and Yamey BS (eds) Accounting History: Some British Contributions. Oxford: Clarendon Press, pp.13-56.

Richardson AJ (2008) Strategies in the development of accounting history as an academic discipline. Accounting History 13(3): 247-280.

Sangster A (2012) Locating the sources of Pacioli's bookkeeping treatise. The Accounting Historians Journal 39(2): 91-110.

Sangster A (2014) Libr. XV: Cotrugli and De Raphaeli on Business and Bookkeeping in the Renaissance. Stirling: Lomax Press.

Sangster A (2015) De Raphaeli ousts Pacioli in accounting history bombshell. Accountancy Ireland 47(1): $8-11$.

Sangster A (2016) The genesis of double entry bookkeeping. The Accounting Review 91(1): 299-315.

Sangster A, Stoner GN and McCarthy PA (2008) The market for Luca Pacioli's Summa Arithmetica. The Accounting Historians Journal 35(1): 111-134. 
Sangster A, Stoner GN, De Lange P, O'Connell B and Scataglini-Belghitar G (2012) Pacioli's forgotten book: The Merchant's Ricordanze. The Accounting Historians Journal 39(2): 27-44.

Sargiacomo M, Servalli S and Andrei P (2012) Fabio Besta. Accounting thinker and accounting history pioneer. Accounting History Review 22(3): 249-267.

Sieveking H (1898) Genueser Finanzwesen mit besonderer Berucksichtigung der Casa di S. Giorgio. Volkswirtshafsliche Abhandlungen der Badischen Hochschulen 1(3): 14-21.

Singhvi NM (1995) Origin of accounting (a case study of ancient Indian literature). In: Special World Conference to Celebrate Frà Luca Pacioli. Milano: Ipsoa, pp.191-193.

Smith CA (1954) Speculations on Roman influence on the theory of double-entry book-keeping. Accounting Research 5(4): 335-342.

Sombart W (1919) Der moderne Kapitalismus: Zweiter Band. Munchen und Leipzig: Duncker \& Humblot.

Stevelinck E (1986) The many faces of Luca Pacioli: Iconographic research over thirty years. The Accounting Historians Journal 13(2): 1-18.

Stevelinck E and Haulotte R (1975) Luca Paciolo: Sa vie, son œuvre et la première traduction en français du premier traité de comptabilité imprimé en 1494 à Venise. Bruxelles: Comptabilité et productivité.

Sy A and Tinker T (2006) Bury Pacioli in Africa: A bookkeeper's reification of accountancy. Abacus 42(1): $105-127$.

Taylor ER (1944) The name of Pacioli. The Accounting Review 19(1): 69-76.

Taylor ER (1956) Luca Pacioli. In: Littleton AC and Yamey BS (eds) Studies in the History of Accounting. Homewood IL: Irwin, pp.175-184.

Van Der Helm AJ and Postma J (2000) La Riegola de Libro. Bookkeeping instructions from the mid-fifteenth century. In: Accounting and History. Madrid: AECA, pp.147-178.

Var T (1981) Bonsignori family estate accounting 1461-1632. The Accounting Historians Journal 8(2): 23-35.

Var T (1992) The ledger of Giacomo Badoer (1436-39) and the Eastern trade. In: Boys P and Freear J (eds) Accounting History 1976-1986 (RLE Accounting): An Anthology. Abingdon: Routledge, pp.117-133.

Viganò E and Mattessich R (2007) Accounting research in Italy: Second half of the twentieth century. Review of Accounting and Finance 6(1): 24-42.

Vlaemminck JH (1956) Histoire et doctrine de la comptabilité. Bruxelles: Éditions du Treurenberg.

Voigt M (1887) Ueber die Bankiers, die Buchführung und die Literalobligation der Römer. Leipzig: Hirzel.

Volmer JGC (1896) Inhoud des boeks. In: Paciuolo Verhandeling Koopmansboekhouding in het Nederlandsch overgebracht. Rotterdam: Kreukniet, pp.XIII-XVII.

Walker SP (2005) Accounting in history. The Accounting Historians Journal 32(2): 233-259.

Walker SP (2009) Structures, territories and tribes. In: Edwards JR and Walker SP (eds) The Routledge Companion to Accounting History. Abingdon: Routledge, pp.11-29.

Ward AW, Prothero GW, Leathes S, Emerich J and Dalberg E (1903) The Cambridge Modern History, Volume 2. Cambridge: Acton University Press.

Weber M (1922) Wirtschaft und Gesellschaft. Tübingen: Mohr.

Williams JJ (1978) A new perspective on the evolution of double-entry bookkeeping. The Accounting Historians Journal 5(1): 29-39.

Winjum JO (1970) Accounting in its age of stagnation. The Accounting Review 45(4): 743-761.

Winjum JO (1971) Accounting and the rise of capitalism: An accountant's view. Journal of Accounting Research 9(2): 333-350.

Woolf AH (1912) A Short History of Accountants and Accountancy. London: Gee \& Co. Ltd.

Yamey BS (1947) Notes on the origin of double-entry bookkeeping. The Accounting Review 22(3): 263-272.

Yamey BS (1949) Scientific bookkeeping and the rise of capitalism. Economic History Review 1(2/3): 99-113.

Yamey BS (1964) Accounting and the rise of capitalism: Further notes on a theme by Sombart. Journal of Accounting Research 2(1): 117-136.

Yamey BS (1967) Fifteenth and sixteenth century manuscripts on the art of bookkeeping. Journal of Accounting Research 5(1): 51-76.

Yamey BS (1970) Closing the ledger. Accounting and Business Research 1(1): 71-77. 
Yamey BS (1979) Compound journal entries in early treatises on bookkeeping. The Accounting Review 54(2): 323-329.

Yamey BS (1981) The Partimenti Account. Abacus 17(1): 3-7.

Yamey BS (1985) The Scuola Palermitana: Some notes on Flori, Pugliesi and Varnei. In: Antoni T (ed) Fourth International Congress of the History of Accountancy. Pisa: ETS, pp.817-830.

Yamey BS (1994) Benedetto Cotrugli on bookkeeping (1458). Accounting, Business \& Financial History 4(1): 43-50.

Yamey BS (2005) The historical significance of double-entry bookkeeping: Some non-Sombartian claims. Accounting, Business \& Financial History 15(1): 77-88.

Zaid OA (2000) Were Islamic records precursors to accounting books based on the Italian method? The Accounting Historians Journal 27(1): 73-90.

Zaid OA (2001) Were Islamic records precursors to accounting books based on the Italian method? A response. The Accounting Historians Journal 28(2): 215-219.

Zaid OA (2004) Accounting systems and recording procedures in the early Islamic state. The Accounting Historians Journal 31(2): 149-170.

Zan L (1994) Toward a history of accounting histories: Perspectives from the Italian tradition. European Accounting Review 3(3): 255-307.

Zan L (2005) Future directions from the past. Management and accounting discourse in historical perspective. Advances in Strategic Management, Vol. 22. Expanding Perspectives on the Strategy Process. Amsterdam: Elsevier, pp.457-489. 